\title{
Constraining post-rift deformation in SE Brazil from U-Pb dating of calcite- mineralized faults
}

\author{
MRS. VIVIANE BARBOSA GIMENEZ, MA ${ }^{1}$, PROF. \\ PETER HACKSPACHER SR., PHD ${ }^{1,2}$ AND EVERTON \\ TIAGO SULATO ${ }^{1}$
}

${ }^{1}$ São Paulo State University (UNESP)

${ }^{2}$ Rio de Janeiro State University (UERJ)

Presenting Author: v.gimenez@unesp.br

Brittle structures often act as potential controllers of local to regional fluid-flow patterns. Calcite mineralization in open fractures may be causally related to their opening process, thus recording key information about timing and tectonic context of mineral growth. Since primary calcite aggregates with crack-seal textures on structural planes may be synchronous to fault movement, calcite $\mathrm{U}-\mathrm{Pb}$ dating can also provide ages of fault (re)activation. Such time constraints are essential especially in areas that have undergone complex tectonic evolution and major landscape changes during Cenozoic. In SE Brazilian passive margin, post-rift tectonics comprise significant reactivations along inherited basement structures due to several changes on intraplate stress fields. Although paleostress analysis imply at least one compressive $\mathrm{SH}_{\max }$ stress field associated with the Continental Rift of Southeast Brazil (CRSB), chronological relations between post-rift tectonic events are still poorly understood. In this context, an NW-SE aulacogen related to South Atlantic break up - the Ponta Grossa Arch - stands out as a major regional feature marked by high-angle faults with calcitemineralized slickensides targeted for investigation. Here we present the first absolute ages of post-rift deformation in SE Brazil from $\mathrm{U}-\mathrm{Pb}$ dating of fault-related calcite in ParanáEtendeka LIP rocks by laser ablation inductively coupled plasma mass spectrometry (LA-ICP-MS). Analyses were performed at the High-Resolution Mass Spectrometry Laboratory of the São Paulo State University (UNESP) using a $193 \mathrm{~nm}$ ns laser with a $100 \mu \mathrm{m}$ spot and a HR-ICP-MS to measure ${ }^{207} \mathrm{~Pb} /{ }^{206} \mathrm{~Pb}$ on NIST 612 glass and ${ }^{206} \mathrm{~Pb} /{ }^{238} \mathrm{U}$ on two reference materials. Measured vs. known ages were considered to calculate a ${ }^{206} \mathrm{~Pb} /{ }^{238} \mathrm{U}$ correction factor. Prior to isotopic analysis, optical, cathodoluminescence and SEM (back-scattered electron) imagery revealed target zones of chemical zonation and primary calcite microtextures typically related to syn-tectonic brittle deformation under high fluid pressures. Our results illustrate a contrasting evolution between the African and South American passive margins, the latter marked by a highly dynamic combination of intraplate stresses from various sources (e.g., Andean slab pull, mid-Atlantic ridge push, crustal thermal contraction and flexural folding due to Santos Basin sediment load) that resulted on widespread strike-slip/oblique faulting throughout the margin during the Cenozoic. 